\title{
Determinant Factors of Food Farming Vulnerability in Banten Province to Support Climate Change Adaptation
}

\author{
Suciantini ${ }^{1}$, Woro Estiningtyas' ${ }^{1}$, Adi Rahman ${ }^{2}$ \\ ${ }^{1}$ Indonesian Agro-Climate and Hydrology Research Institute (IAHRI), Ministry of Agriculture, Jalan Tentara Pelajar No. 1A, \\ Cimanggu, Bogor, Indonesia 16111 \\ ${ }^{2}$ Centre for Climate Risk and Opportunity Management in Southeast Asia Pacific, Baranangsiang Campus, IPB University, Jalan \\ Pajajaran Bogor, Indonesia 16143
}

\section{ARTICLE INFO}

\section{Received}

16 July 2020

\section{Revised}

21 September 2020

\section{Accepted for Publication}

11 November 2020

\section{Published}

29 Desember 2020

doi: 10.29244/j.agromet.34.2.129-142

\author{
Correspondence: \\ Suciantini \\ Indonesian Agro-Climate and \\ Hydrology Research Institute (IAHRI), \\ Ministry of Agriculture, Jalan Tentara \\ Pelajar No. 1A, Cimanggu, \\ Bogor, Indonesia 16111 \\ Email: suciantini@yahoo.com
}

\section{This is an open-access article} distributed under the CC BY License. (C) 2020 The Authors. Agromet.

\begin{abstract}
A B S T R A C T
Food crop is one of the most impacted agricultural sectors by climate related disaster. The negative impacts of climate related disaster could be assessed by its vulnerability level that depends on various indicators including exposure, sensitivity, and adaptive capacity. This paper aims to identify the determinant factors that influence the vulnerability of food farming based on the characteristics of land resources, climate and water, and socio-economic factors at the district level in Banten Province, and to develop recommendations on climate adaptation. Identification of the dominant factors, which most contribute to the level of vulnerability, is one of the main considerations to determine the strategy of adaptation. Our results showed that the main determinant factors varied among districts. The most important factors were Oldeman's climate type (SEI12), the ratio of the number of extension agents to rice field area (ACI3), and the ratio of the number of farmer groups to rice field area (ACI4). SEI12 deals with the climate, whereas $\mathrm{ACI} 3$ and $\mathrm{ACI} 4$ are related human resources and institutions. Further, although urban area had high exposure and sensitivity as in rural area, but the adaptive capacity for the urban area was still high. Therefore, the level of vulnerability was reduced in urban, but still high in rural area. More efforts are expected to adapt climate related disaster in rural area.
\end{abstract}

\section{KEYWORDS}

agricultural sector, adaptive capacity index, local adaptation, sensitivity-exposure index, technology recommendation

\section{INTRODUCTION}

Climate change has become a very strategic issue for the last two decades. Nowadays, the frequency of climate related disasters, as the climate change impacts, is becoming more frequent. The frequent disasters can disrupt national food production and crop's productivity. Therefore, many efforts should be taken to adapt climate change impacts on agriculture sector, since the sector is the most vulnerable sectors effected by climate variability and climate change (Kukal and Irmak, 2018; Menike and Arachchi, 2016). For instance, climate change can have indirect impact to farmers' income due to crop failure or decreased productivity (Rondhi et al., 2019; Saptutyningsih et al., 2020), which can lead to negative impacts on their food security (Alam et al., 2017; Bocchiola et al., 2019). To increase resilience on agriculture sector, the impact of climate change on agriculture vulnerability level is urgently to be accounted (Mallari, 2016). Also, the production risks related to adaptation action, which is suitable for policymakers, needs for estimation (Reinmuth et al., 2017). To improve resilience of agriculture sector to climate related disaster, information on current and future vulnerability, risks, and opportunities is required for better planning and management of agriculture sector in the future (Cains and Henshel, 2019).

The level of vulnerability is an important indicator to determine the magnitude of climate change impacts. Vulnerability is a measure of the nega- 
tive impacts of climate change that a system cannot tolerate (Boer et al., 2015a; Chinwendu et al., 2017). Climate change can have an impact on three dimensions of vulnerability; the level of sensitivity and adaptation of an area, the level of exposure to climate change, and the threat of disasters that occurs in the region (Thomas et al., 2019). Higher exposure and sensitivity result in increased vulnerability. The level of sensitivity is closely related to the level of vulnerability of the system in response to the adverse impacts, while the level of adaptation is the ability of the system to overcome the adverse impacts (Wichern et al., 2019). These three dimensions are complex interactions of several important factors, namely; human, natural, financial, social, and physics (Pandey et al., 2017). The important factors comprise of social and biophysical aspects that need to be considered in a holistic approach to vulnerability analysis (Lee, 2017). Vulnerability is dynamic and contextual, which is determined by the continuous interaction of various exogenous and endogenous stressors in addition to the associated components that interact with the vulnerability (Naylor et al., 2020), such as the affected system (Morel et al., 2019) and potential loss or danger (Noy and Yonson, 2018). In addition, the existence of institution may alter the vulnerability (Rufat et al., 2015). Climate vulnerability factors are required to be anticipated by performing long-term actions (Jakariya et al., 2020) by formulating adaptation strategies to address vulnerabilities and developing technology-based solutions.

Determinant factor is a very important stage to be examined carefully in vulnerability analysis. Determinant factors can be considered as determinant of vulnerability, also as benchmarks for comparison on national scale (Sujakhu et al., 2018). Vulnerability assessment may differ significantly in the same geographic area, depending on the indicators selected, the weighting mechanisms, and the methods used (Neset et al., 2019). Considering that vulnerability differs among regions, the management of vulnerability is highly dependent on local management (PapathomaKöhle et al., 2019). Perdinan et al. (2015) stated that the preparation and implementation of adaptation at the local level are closely related to the understanding, socio-economic conditions of the community, and the preparation of adaptation programs. This was consistent to other study in Italy (Papathoma-Köhle et al., 2019) that mentioned indicators of vulnerability were not generally applicable in all regions. There were three approaches for vulnerability analysis, including mechanistic, correlative, and trait-based (de los Ríos et al., 2018). The mechanistic approach utilizes process-based analysis, such as biological processes analysis, energy equilibrium equations and interactions, etc. The corre- lative approach includes predicting changes in species distribution due to climate change. The trait-based approach combines the components of vulnerability (exposure, sensitivity, and adaptive capacity) with selected biological features.

In agricultural sector, vulnerability is technically related to land use systems and soil properties, cropping patterns, management of soil, water and crop, and crop varieties (Kantamaneni et al., 2020). Determinant factors of vulnerability in crop farming are required to rule the direction and strategies of adaptation programs, therefore the high vulnerability level can be avoided or reduced. Determinant factors are the dominant determinants of sensitivity, exposure, and adaptive capacity. Increased vulnerability is expected when the level of exposure and sensitivity is high (Koutroulis et al., 2019). Improvement of food vulnerability indicator will have a direct or indirect impact on food security. By undertanding the determinant factors in a certain area, it is possible to determine the selection of adaptation technology according to regional conditions. Tyler et al. (2016) explained that there were several criteria for indicators selection, namely: (i) observable and verifiable, (ii) quantitative or qualitative, (iii) relevant to local decision making, (iv) specific, (v) measurable, (vi) actionable, (vii) dynamic, and (viii) dependent on available data.

The adaptive capacity index (ACI) and the sensitivity-exposure index (SEI) are functions that represent the vulnerability index of lowland agriculture related to climate change (Boer et al., 2015b; Estiningtyas et al., 2016a). ACI is calculated based on indicators related to adaptation activities that affect the level of agricultural vulnerability. SEI is calculated based on indicators that are vulnerable to exposure and sensitive when climate change occurs. Assessment of vulnerability level used the quadrant method and weighting method. ACI is plotted on the X-axis and SEI on the Yaxis, because to the level of vulnerability, adaptation is inversely proportional while exposure and sensitivity are directly proportional. The distribution of vulnerability level of food farming ranges from very low to very high. Here, we applied ACI and SEI approach to analyze vulnerability level of agriculture sector in Banten Province. Previous studies revealed that this province was affected by climate related variability and change (Estiningtyas et al., 2016b; Mulyaqin, 2020). In Banten, four districts (Pandeglang, Lebak, Serang, and Tangerang) were categorized as very high level of vulnerability to crop farming (Estiningtyas et al., 2016b).

However, the cause of very high vulnerability in the four districts remains research challenge, therefore information on the determinant factors affecting very high vulnerability is required. This study aims to identify 
the determinant factor affecting vulnerability of crop farming based on aspect of land, climate, water, and socio-economic activities in district level. Also, to propose policy recommendations related to climate change adaptation based on vulnerability level.

\section{RESEARCH METHODS}

\section{General Conditions of Banten Province}

Banten Province is geographically located at the western Java Island, between $5^{\circ} 07^{\prime} 50$ "- $7^{\circ} 01^{\prime} 1^{\prime \prime} \mathrm{S}$ and $105^{\circ} 01^{\prime} 11^{\prime \prime}-106^{\circ} 07^{\prime} 12^{\prime \prime} \mathrm{E}$, and is directly adjacent to West Java Province and DKI Jakarta. This province has an area of $9.663 \mathrm{~km}^{2}$ or only $0.51 \%$ of the entire land area of Indonesia. Topographically, the altitude ranges 0-2000 $\mathrm{m}$ above sea level, but most area are located in the lowland area $(<200 \mathrm{~m}$ asl). The altitude higher than $200 \mathrm{~m}$ asl is partly found in Lebak, Pandeglang, and Serang Regency. Locations above $1,000 \mathrm{~m}$ are mountainous area around Mount of Halimun. In Banten, administratively there are four regencies (Pandeglang, Lebak, Tangerang, and Serang), and four cities (Tangerang, Cilegon, Serang, and South Tangerang) (The Central Bureau of Statistics of Banten Province, 2016).

The weather is dominated by the westerly wind especially in rainy season from the Indian Ocean, and the easterly wind in dry season, which form monsoonal type of rainfall. Figure 1 presents the monsoonal type of monthly rainfall from several districts for 2005-2014. The amount of rainfall in this province is influenced by El Niño Southern Oscillation (ENSO), such as in 2015 when the annual rainfall was low $(1,385 \mathrm{~mm})$ in 142 days (BMKG, 2015). Assessment on the food farming vulnerability used several aspects including land, climate, water resource parameters, and the support of socio-economic data (Estiningtyas et al., 2016b). We set year of 2014 as a reference for further analysis. The input data of vulnerability analysis are listed in Table 1. The availability of rainfall data from rain stations varies across districts, therefore there was variation in length data used. Overall, the data started from 1975 until 2015 with the length data varied from 20 to 35 years.

Determination of Indicators for the Adaptive Capacity Index and the Sensitivity-Exposure Index

We determined the Adaptive Capacity Index (ACI) and the Sensitivity-Exposure Index (SEI) based on many indicators that are listed in Table 2. The selected indicators were related to food farming vulnerability, and they were adjusted according to the availability of representative data. In food farming vulnerability, there are determinant factors that represent the components of land resources namely the availability of water (watershed criticality), soil fertility, and Oldeman climate type. In contrast to current approach on the vulnerability analysis (e.g. Boer et al., 2015a; Estiningtyas et al., 2016a), we improved SEI calculation by adding three indicators namely: water availability (SEI8), soil fertility level (SEI9), and Oldeman climate type (SEI12) (Estiningtyas et al., 2016b).

\section{Determinant Factors of Food Farming Vulnerability}

The determinant factors may act as indicator of vulnerability that greatly contributes to the level of vulnerability, therefore determinant factors are firstly determined before establishing the appropriate adaptation efforts in a specific area. In this research, determinant factors were identified using the spider web diagram method for each ACI and SEI (Estiningtyas et al., 2016b). ACI was calculated based on indicators assuming they can affect the level of adaptation to food farming vulnerability. On other hand, indicators that were assumed can affect the level of sensitivity and exposure were used to calculate SEI. All indicators used to calculate ACI and SEI (Table 2) were weighted based on their contribution to the index. Here, the weighting method was implemented by expert judgment (Estiningtyas et al., 2016a, 2016b).

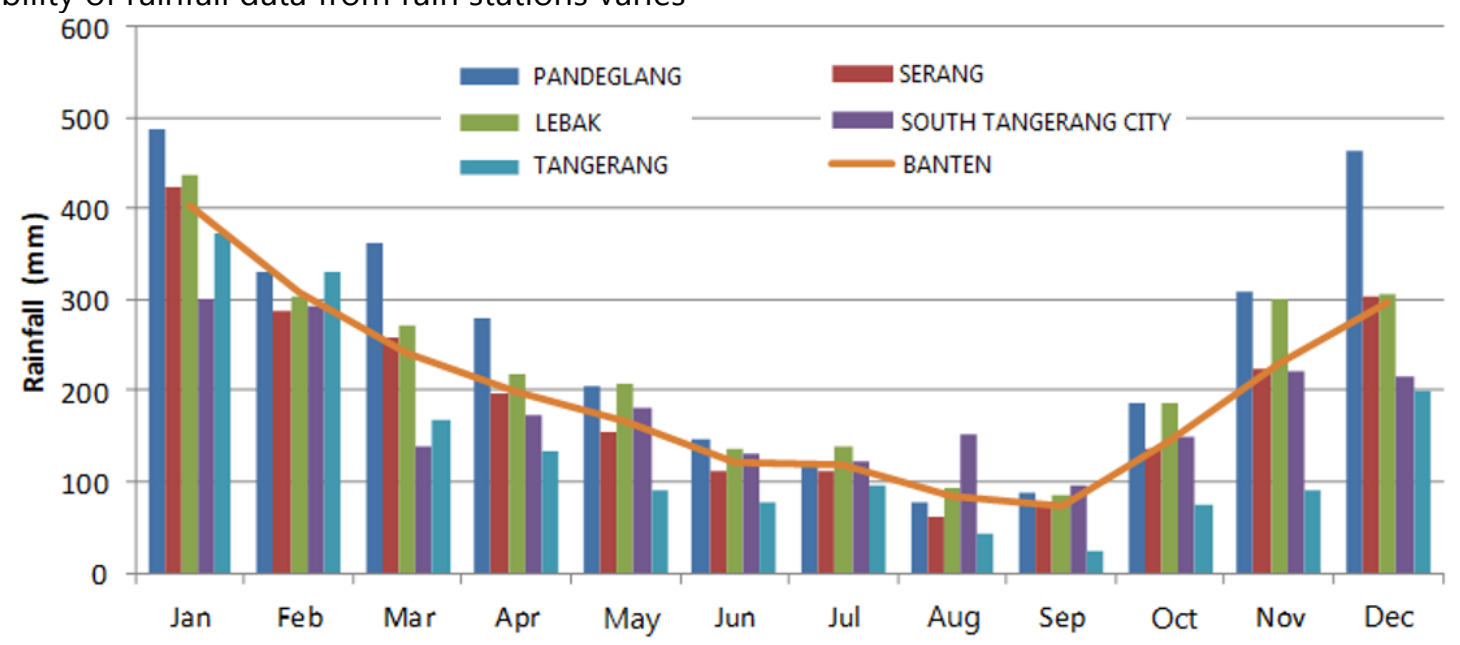

Figure 1. Monthly rainfall in several districts in Banten Province and average rainfall in Banten Province (BMKG, 2015). 
Table 1. List of the research data used in this study

\begin{tabular}{|c|c|c|c|}
\hline No. & Data & Resolution & Source \\
\hline 1 & Soil map & $1: 250,000$ & $\begin{array}{l}\text { Indonesian Center for Agricultural Land Resources } \\
\text { Research and Development/ICALRRD (BBSDLP) in } \\
\text { 1998-2015 }\end{array}$ \\
\hline 2 & Ricefield map & 1: 5,000 & $\begin{array}{l}\text { Center for Data and Information System- Ministry } \\
\text { of Agriculture (Pusdatin) in } 2014\end{array}$ \\
\hline 3 & Rainfall & - & $\begin{array}{l}\text { Meteorological, Climatological, and Geophysical } \\
\text { Agency (BMKG), Ministry of Publik Work, } \\
\text { Indonesian Agro-Climate and Hydrology } \\
\text { Institute/IAHRI (Balitklimat) database (1975-2015) }\end{array}$ \\
\hline 4 & Type and area of irrigation & - & The Central Bureau of Statistics (BPS) in 2014 \\
\hline 5 & Number of reservoirs per area & - & Ministry of Publik Work in 2014 \\
\hline 6 & Length of irrigation network per area & - & Ministry of Publik Work in 2014 \\
\hline 7 & Crop production & - & The Central Bureau of Statistics (BPS) in 2014 \\
\hline 8 & Land area & - & The Central Bureau of Statistics (BPS) in 2014 \\
\hline 9 & Harvested area & - & The Central Bureau of Statistics (BPS) in 2014 \\
\hline 10 & Farmer household & - & $\begin{array}{l}\text { National Socio-Economics Survey Data } 2013 \text { The } \\
\text { Central Bureau of Statistics (Susenas-BPS) }\end{array}$ \\
\hline 11 & School participation rate & - & The Central Bureau of Statistics (BPS) in 2014 \\
\hline 12 & $\begin{array}{l}\text { Road length according to surface } \\
\text { conditions }\end{array}$ & - & The Central Bureau of Statistics (BPS) in 2014 \\
\hline 13 & Number of extension agents & - & $\begin{array}{l}\text { Center for Data and Information System-Ministry } \\
\text { of Agriculture (Pusdatin) in } 2014\end{array}$ \\
\hline 14 & Number of farmer groups (Poktan) & - & $\begin{array}{l}\text { Center for Data and Information System-Ministry } \\
\text { of Agriculture (Pusdatin) in } 2014\end{array}$ \\
\hline 15 & $\begin{array}{l}\text { Number and types of agricultural } \\
\text { machinery }\end{array}$ & - & Integrated Cropping Calendar version 2.4 \\
\hline 16 & Food consumption & - & $\begin{array}{l}\text { National Socio-Economics Survey Data } 2013 \text { The } \\
\text { Central Bureau of Statistics (Susenas-BPS) }\end{array}$ \\
\hline 17 & Food expenditure & - & $\begin{array}{l}\text { National Socio-Economics Survey Data } 2013 \text { The } \\
\text { Central Bureau of Statistics (Susenas-BPS) }\end{array}$ \\
\hline 18 & Percentage of poor people & - & The Central Bureau of Statistics (BPS) in 2014 \\
\hline 19 & $\begin{array}{l}\text { Gross Regional Domestic Product } \\
\text { (GRDP) }\end{array}$ & - & The Central Bureau of Statistics (BPS) in 2014 \\
\hline 20 & $\begin{array}{l}\text { Coefficients to measure the income } \\
\text { and wealth gap (GINI index) }\end{array}$ & - & $\begin{array}{l}\text { National Socio-Economics Survey Data } 2013 \text { The } \\
\text { Central Bureau of Statistics (Susenas-BPS) }\end{array}$ \\
\hline 21 & Agroclimate type & - & Oldeman (1975) \\
\hline 22 & Population density & - & The Central Bureau of Statistics (BPS) in 2014 \\
\hline 23 & Indonesian administration & - & $\begin{array}{l}\text { The Central Bureau of Statistics (BPS) and the } \\
\text { Geospatial Information Agency (BIG) in } 2013\end{array}$ \\
\hline
\end{tabular}

\section{Weighting of ACI and SEI for Vulnerability Index analysis}

To obtain indicator value between 0 and 1 , all of data were normalized, ranked, and weighted. Estiningtyas et al. (2016b) mentioned that the weighting was subjective depending on the knowledge of experts related to the important indicators' relevance for the level of consumption and production. Equation (1) and (2) are used for computing ACI and SEI.

$$
\begin{aligned}
& A C I=\frac{1}{\mathrm{~W}_{\mathrm{ACI}}}+\sum \mathrm{W}_{\mathrm{pi}} \cdot \mathrm{I}_{\mathrm{pi}} \\
& \mathrm{SEI}=\frac{1}{\mathrm{~W}_{\mathrm{SEI}}}+\sum \mathrm{W}_{\mathrm{ci}} \cdot \mathrm{I}_{\mathrm{ci}}
\end{aligned}
$$

where $\mathrm{i}$ = the $\mathrm{i}$-th weighting factor, $\mathrm{W}=$ the weight for each indicator from the $i$-th district, and I = the vulnerability indicator (Estiningtyas et al., 2016b).

The ACI and SEI were then plotted on the spider web diagram separately, based on all indicators that constructed each index. The determinant factor for the SEI was obtained by identifying indicators that have a substantial contribution to vulnerability, which resulted in a high index value. On the spider web diagram, the determinant factor of SEI was identified by the indicators that have a value $>0.5$, whereas an indicated value 
$<0.5$ for $\mathrm{ACI}$. The determinant factor for ACI means that the indicators need improvement (Estiningtyas et al., 2016b).

\section{Survey and Interview}

Based on the level of vulnerability and the determinant factors that affected the vulnerability, various adaptation efforts were identified. Further, to decide adaptation efforts that can be implemented, a survey was carried out by interviewing policymakers, extension officers, or farmer groups to collect information on each district based on previous research (Estiningtyas et al., 2016b). Field survey to verify applicable technology related to land and water resources was done in Pandeglang and Lebak Districts.

\section{Food Farming Vulnerability in Banten Province}

Previous study revealed that there were four districts in Province Banten, in which their food farming vulnerability was categorized as very high level (Estiningtyas et al., 2016b). The same study also reported that one district was in medium vulnerability, while three districts had low vulnerability level. Districts that were categorized as very high concentrated in Pandeglang, Lebak, Serang, and Tangerang (Figure 2). More actively adaptation actions were proposed in the highly vulnerable districts to increase adaptation capability of the district in response to climate change. The vulnerability level indicates that the higher the vulnerability of district, the more sensitive the district to climate change (Handayani et al., 2017). The area affected by climate change even in a low scale was more intense in the area having low vulnerability compared to the area that not vulnerable. In areas with medium and low levels of vulnerability, which were generally located in urban areas (Figure 2), it is possible to have better adaptation readiness, because they had a wider adaptation or were not sensitive to climate shocks (Estiningtyas et al., 2016b).

\section{RESULTS AND DISCUSSIONS}

\section{Determinant Factors of Food Farming Vulnerability in Banten Province}

Figure 3 presents the vulnerability level for Banten Province, which shows contribution of each indicator (determinant factor) that affects ACI and SEI. Based on our analysis, area with high vulnerability needs more adaptation actions. To increase adaptation capacity, determinant factor should be improved. For ACI, determinant factors included; $\mathrm{ACI} 3$ (ratio of the number of extension workers to rice field area), ACI4 (ratio of total farmer groups (poktan) to rice field area), ACI2 (road length based on surface conditions), ACI1 (school participation rate), and ACI6 (ratio of food consumption to total household expenditure).

On other hand, the high vulnerability area was treated by lowering SEI indicators. The determinant factors of SEI included; SEI12 (Oldeman climate type), SEI3 (entropy), SEI1 (ratio of rice consumption to total carbohydrate food), SEI8 (water availability (criticality level of the watershed)), SEI15 (ratio of agricultural food land area to area), SEI9 (soil fertility level) ), SEI4 (ratio of expenditure on rice to total expenditure on food), SEI6 (ratio of rice and maize production to population), SEI10 (ratio of agricultural GRDP to total GRDP), SEI7 (ratio of soybean production to population), and SEI13

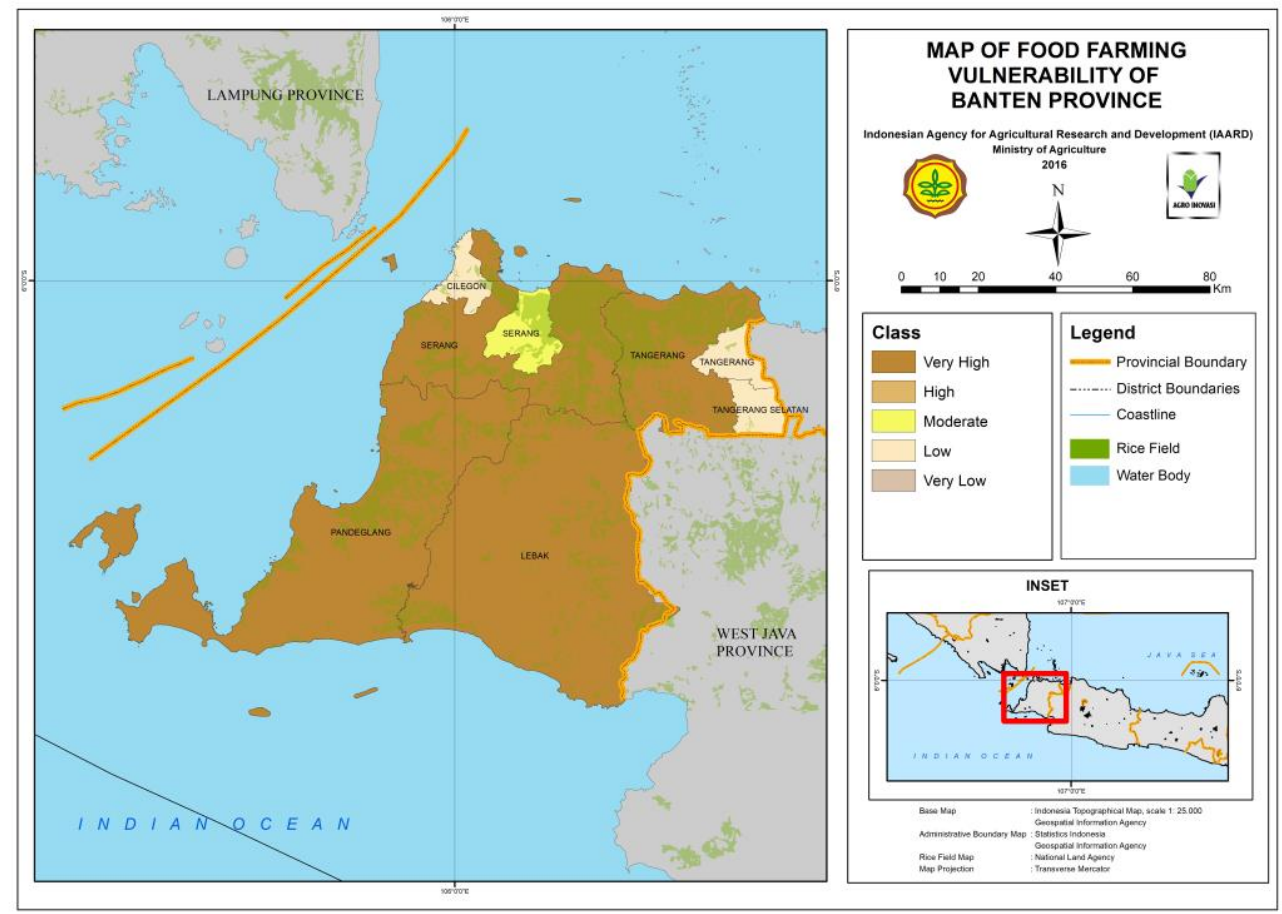

Figure 2. Map of Food Farming Vulnerability of Banten Province (Estiningtyas et al., 2016b). 
Table 2. Input data to represent the indicator of Adaptive Capacity Index (ACI) and SensitivityExposure Index (SEI)

\begin{tabular}{ll}
\hline Indicators & Definition \\
\hline & Adaptive Capacity Index (ACI) \\
\hline ACI1 & School Participation Rate \\
\hline ACI2 & Road length based on surface conditions \\
\hline ACI4 & Ratio of the number of extension agents to rice field area \\
\hline ACI5 & Ratio of the number of farmer groups (poktan) to rice field area \\
\hline ACI6 & Ratio of the value of food consumption to the total value of household expenditure \\
\hline & Sensitivity-Exposure Index (SEI) \\
\hline SEI1 & Ratio of rice consumption to total carbohydrate food \\
\hline SEI2 & Rice consumption per capita \\
\hline SEI3 & Entropy (food diversification level) \\
\hline SEI5 & Ratio of expenditure on rice to total expenditure on food \\
\hline SEI6 & Percentage of poor people \\
\hline SEI7 & Ratio of rice and maize production to total population \\
\hline SEI8 & Water availability \\
\hline SEI9 & Soil fertility level \\
\hline SEI10 & Ratio of agricultural GRDP to total GRDP \\
\hline SEI11 & GINI index (income gap) \\
\hline SEI12 & Climate type (Oldeman) \\
\hline SEI13 & Ratio of farmer households to total households \\
\hline SEI14 & Population density \\
\hline SEI15 & Ratio of land area for agriculture to total area \\
\hline Soure : Estingtion to to population \\
\hline
\end{tabular}

Source : Estiningtyas et al. (2016a, 2016b)

(ratio of farmer households to total households). Understanding both the ACI and SEI indicators, which were as determinant factors, can be a basis for formulating appropriate programs for local governments in response to threat of climate change, and in efforts to improve food security and community welfare, in this case, the farming community in the implementation of food farming.

To increase the ACI indicators, several efforts are listed here (Estiningtyas et al., 2016b);

1. ACI3 (ratio of the number of extension workers to rice field area), needs: (i) improvement on the extension agency, guidance, and supervision, (ii) improvement on the welfare of extension workers, and (iii) recruitment the new member of extension workers;

2. ACI4 (ratio of total farmer groups (poktan) to rice field area), was by recruitment more farmers to increase the number of farmer groups. Other efforts were by improving farmer institutions and empowering the capacity of farmer groups;
3. ACI2 (road length based on surface conditions). Government should build or repair farming infrastructure. Therefore, the distribution of food products goes well;

4. ACI1 (school participation rate), were by supporting the 12-years compulsory education program, by equitable distribution of educational facilities, and by providing learning modules related to technical aspects;

5. ACI6 (ratio of the value of food consumption to the total value of household expenditures). The efforts to diversify food and develop local nonrice food can be encouraged. The lower food consumption than food production, the higher adaptive capacity.

To reduce the SEI indicators, several actions could be performed (Estiningtyas et al., 2016b);

1. SEI12 (Oldeman climate type), efforts that can be implemented include: (i) adjusting farming to climate conditions, (ii) following the planting calendar, and (iii) providing alternative irrigation and irrigation infrastructure; 
2. SEI3 (entropy) and SEI1 (ratio of rice consumption to total carbohydrate food), it was recommended to plant in yards to fulfill household needs and to develop local non-rice for food diversification;

3. SEI8 (the availability of water-criticality level of the watershed), were by: (i) restoration of critical watersheds, (ii) improvement and development of infrastructure and irrigation networks, and (iii) socialization and implementation of water-saving cultivation technology. Activities related to water availability have been programmed by the Banten Provincial Government as listed in Banten Provincial Regulation No. 5 of 2017 namely integrated watershed development, development of reservoirs, and construction of irrigation channels (Bappeda Provinsi Banten, 2017);

4. SEI15 (ratio of land area for food agriculture to total area), were by open new agricultural land and transmigration;

5. SEI9 (level of soil fertility), efforts to reduce SEI were by implemented: (i) the tolerant rice and efficient fertilization, (ii) balanced and site specific fertilization, and (iii) soil and water conservation;

6. SEI4 (ratio of expenditure on rice to total expenditure), were by food diversification, controlling rice prices, and non-rice food subsidies;

7. SEI14 (population density), the recommendation was transmigration, which was adjusted to the Agrarian reform;

8. SEI6 (ratio of production of rice and maize to population) and SEI7 (ratio of soybean production to population). It was recommended to increase the production of these commodities;

9. SEI10 (ratio of agricultural GRDP to total GRDP), were by drive the regional economy, increase agricultural GRDP, and promote micro-scale industrial activities and businesses;

10. SEI13 (ratio of farmer household to household population), was by improving the skills of farmers through training and development of non-agricultural businesses.

\section{Determinant Factors of Food Farming in District Level}

Pandeglang and Lebak Districts had similar determinant factors for $\mathrm{ACI}$, namely $\mathrm{ACI} 1, \mathrm{ACI} 2, \mathrm{ACI} 3$, $A C I 4$, and ACI6 (Figures 4a and 4c). The ratio of food consumption value (ACI6) may be raised by improving diversification of food, while the improvement on number of extension officers in each district will increase the value of $A C I 3$ indicator. The school participation rate (ACI1) is risen by complying the 12-years compulsory education. Enhancement on the role of the institution in the village and active participation of farmers in the meeting and related training will raise the ratio of the number of farmer groups (ACI4). Good transportation facilities and road infrastructure are all supporting factors that make it easier for farmers to get the needs for cultivation (Estiningtyas et al., 2016b) that probably increase the ACI2.

The determination of determinant factors for SEI covers 15 types. The 3-dominant determinant factors for SEI in Pandeglang were SEI1, SEI3, and SEI4, while in Lebak were SEI8, SEI7, and SEI12. Those determinant factors for SEI were management priorities to increase the adaptation capacity. For example, in SEI12, several efforts were listed such as adjusting crop cultivation, cropping patterns, planting time, planting intensity, and varieties based on the type of climate in the location. Hence, losses due to climate risk can be minimized. The use of an integrated planting calendar is one of the recommended efforts.

Another example is the ratio of expenditure on rice to total expenses (SEI4). To reduce the SEI4, it needs

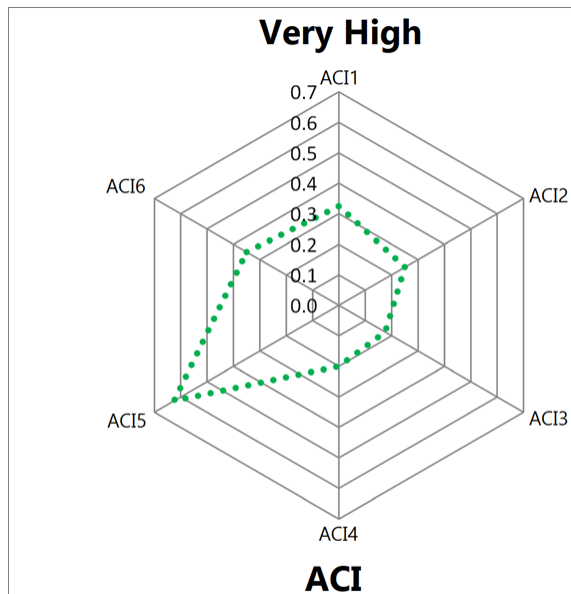

(a)

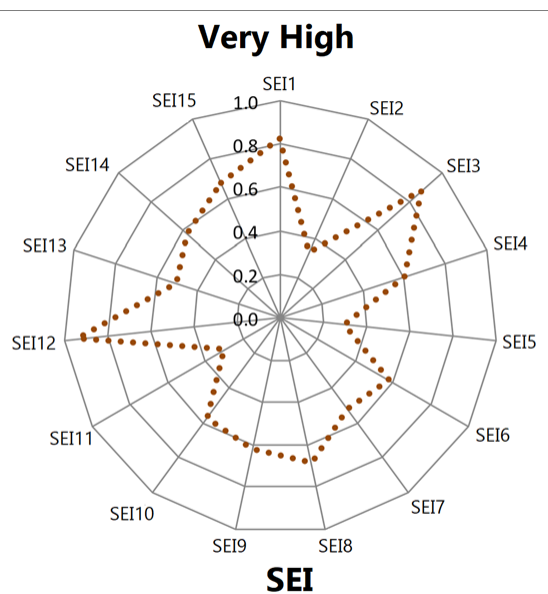

(b)

Figure 3. Spider graph of ACI (a) dan SEI (b) at a very high level of vulnerability in Banten Province (Estiningtyas et al., 2016b). 
several strategies to reduce household rice consumption, therefore it will reduce the dependence of rice. The strategies were among others: food diversification, increase income that lead the variation consumption, stable rice prices, provide subsidies for non-rice food, and build sustainable food home areas (KRPL). One study analyzed that KRPL program was able to reduce expenditure on food consumption and to increase energy and protein consumption (Purwantini et al., 2016).

The determinant factors for ACI in Serang were ACI4, ACI3, ACI2, ACI1, and ACI6 (Figure 4e), while for SEI, the 3-dominant determinant factors include SEI12, SEI3, and SEI1 (Figure 4f). In Tangerang, the determinant factors for $\mathrm{ACI}$ were $\mathrm{ACI} 2, \mathrm{ACI} 3, \mathrm{ACI} 4, \mathrm{ACI}$, and ACI1 (Figure 4g). On other hand, the 3-determinant factors of SEI in Tangerang include; SEI12, SEI3, and SEI14 (Figure 4h). Based on the main determinant factors in each district (Figures 4 and 5), SEI12 was the main indicator that was found in many districts. SEI12 associated with climate, especially rainfall and its distribution. Therefore, the right solution to minimize the loss of food farming related to climate risk is necessary. For rainfall variable, there were two parameters that were considered for analysis namely the beginning of rainy season and the length of rainy season. In response to crop cultivation, rainfall influenced the availability of water that can affect the productivity and production of crop farm. Previous studies reported that rainfall substantially influences the development of food crops (Estiningtyas et al., 2020; Farhan et al., 2020). Generally, the length of rainy season in Banten was around 3 to 6 months, with the beginning season in October and November. Several efforts to minimize the production losses include; providing alternative water sources, adjusting farming to climate conditions, implementing a planting calendar, and developing irrigation infrastructure.

In districts with a very high level of vulnerability, such as in Pandeglang, Lebak, Serang, and Tangerang, the following indicators of SEI were dominant in addition to SEI12, namely SEI1, SEI3, SEI4, and SEI10. The indicators of SEI1, SEI3, and SEI4 are related to food, therefore similar efforts may work to decline their indicator values. The efforts were among others; diversifying food especially from rice to non-rice with preferably local food, developing non-rice food technology, controlling rice prices and non-rice food subsidies, implementing $\mathrm{KRPL}$, and increasing income (Estiningtyas et al., 2016b).

Food diversification is related to consumption patterns, public food expenditure, and public protein consumption. To increase food security in Indonesia, food diversification was proposed (Ariani, 2019). Food diversification can be done with increasing the con- sumption of yams, animal food, vegetables, and fruit, but by reducing the rice consumption.

From the ACI perspective, the main determinant factors that were required to improve were $\mathrm{ACI} 3$ and ACI4. Several actions to increase the performance or both factors included an increase of human resource capacity and its institutional resource. For instance; (i) improving extension agencies, (ii) assigning new extension officers, (iii) improving advocation and control, (iv) improving welfare to increase the work ethic of extension workers, (v) improving farmer group institutions (poktan), (vi) increasing the number of farmer groups (poktan), and (vii) increasing the capacity of poktan and empowering poktan (Estiningtyas et al., 2016b).

Figures 4 and 5 show that in urban areas with low to medium level of vulnerability. The urban areas may still have an exposure or sensitivity, but high adaptive capacity. Therefore, some urban areas like in Tangerang City did not have determinant factor of $\mathrm{ACI}$, indicating the high ability to adapt in urban area. The high adaptability can reduce the level of sensitivity or exposure. However, different situation was found in rural area, where each adaptation was relatively low.

\section{Recommendations for Adaptation Technology in Banten Province}

Adaptation technology recommendations were compiled based on determinant factors, and were aligned with adaptation actions and programs as listed in the Regional Medium-Term Development Plan (RPJMD). The recommendations aim to reduce the level of vulnerability through adaptation option of climate change. The knowledge about vulnerability level can be used by policymakers to decide the appropriate policies related to climate risk (Ford et al., 2018). But recommendations were site-specific according to each district.

Table 3 presents adaptation efforts that can be performed according to the determinant factors of $\mathrm{ACI}$ and SEI in Banten Province. The survey and interview were performed in Pandeglang and Lebak Districts. The two districts are agricultural areas that are prone to floods or drought. The prone areas were found in southern Pandeglang, including Patia Sub-district and Pagelaran Sub-district. For Lebak, the prone areas were in Warung Gunung Sub-district and Malingping Subdistrict. Based on our survey, generally cropping pattern of rice was twice a year, but three times a year for area with sufficient water.

\section{Survey and Interview Results}

Agricultural activities were supported by use of agricultural machinery, especially tractors and combine harvesters. There was an action on Rural Food SelfSufficiency Program (Program Desa Mandiri Pangan) starting from 2012, in the form of coordination in meet- 
ings and supervising. Several obstacles faced by the farming community in the two case study area were: (i) human resources (not having extensive land, too many farmers, and field agricultural extension activity needs improvement), (ii) geographic location (more rainfed land, but less irrigated land), (iii) road infrastructure, (iv) silting rivers, $(v)$ the planting calendar has not been well socialized to farmers, (vi) pests (especially brown planthopper and stem borer), (vii) high conversion of agricultural land, and (viii) high salinity in some locations. In Lebak, several actions have been performed to support agricultural activities among others the

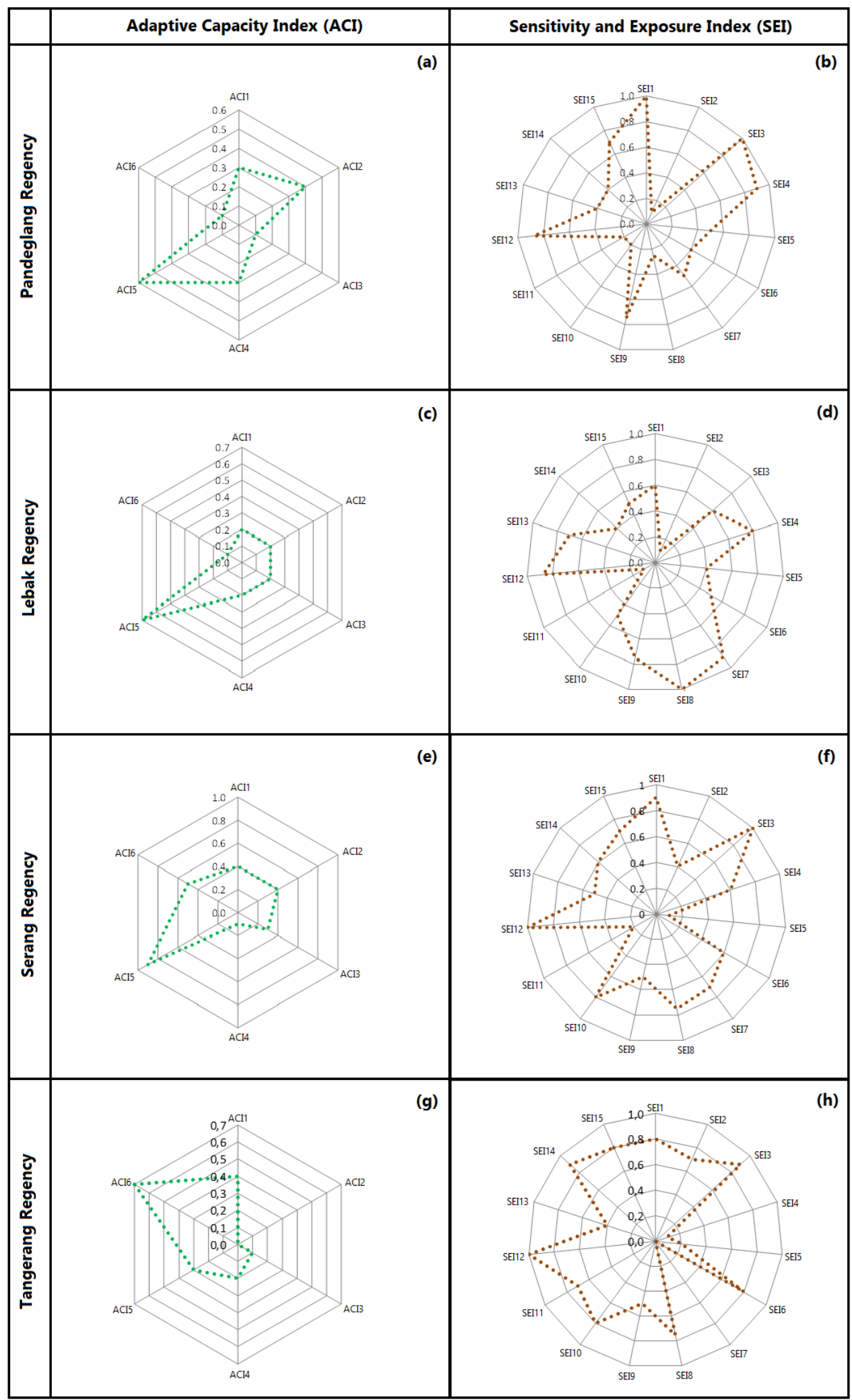

Figure 4. The spider web diagram (left) for ACI in District (a) Padeglang, (c) Lebak (e) Serang, and (g) Tangerang. The spider web diagram (right) for SEI in District (b) Pandeglang, (d) Lebak, (f) Serang, and (h) Tangerang. 
use of submersible pumps (boreholes) from the government to overcome drought and agricultural machinery such as tractors. Several farmers have already participated in insurance for agriculture, and other farmers have implemented the jajar legowo cropping system. Problems faced by farming communities in both the case studies are generally similar to Pandeglang, such as; human resources (cultivated land is not wide, lack of agricultural extension agents), water availability, floods due to dam

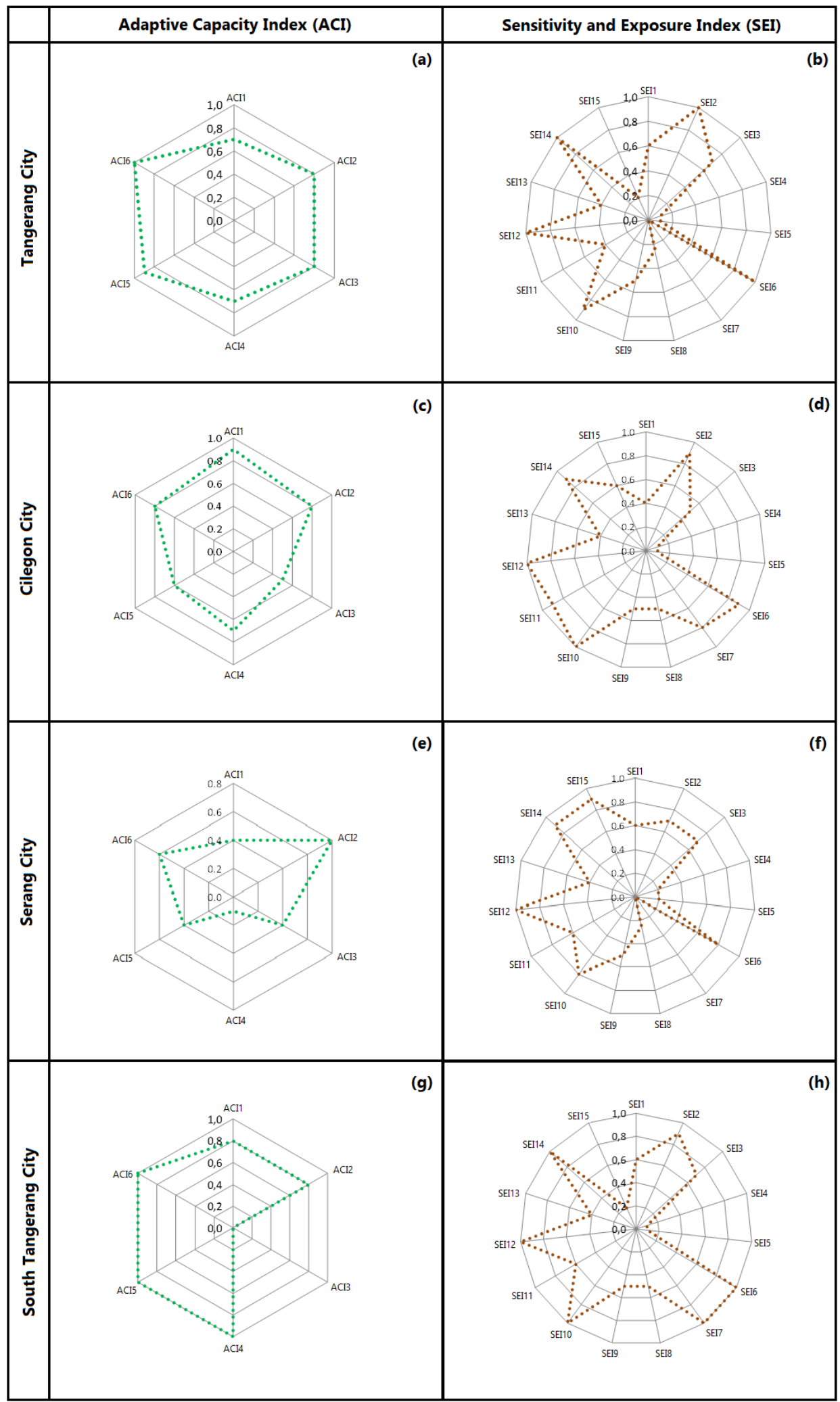

Figure 5. The spider web diagram (left) for ACI in City of (a) Tangerang, (c) Cilegon, (e) Serang, and (g) Tangerang Selatan. The spider web diagram (right) for SEI in City of (b) Tangerang, (d) Cilegon, (f) Serang, and $(h)$ Tangerang Selatan. 
Table 3. Technology recommendations based on determinant factors for ACI and SEI in Banten Province (modified from Estiningtyas et al., 2016b)

\begin{tabular}{|c|c|c|}
\hline Determinants & Districts & Recommendations \\
\hline & Adaptive Capacity Index (ACI) & \\
\hline ACI1 & $\begin{array}{l}\text { Pandeglang, Lebak, Serang } \\
\text { Regency, Tangerang Regency, } \\
\text { Serang City }\end{array}$ & $\begin{array}{l}\text { 12-year compulsory education program, equitable distribu- } \\
\text { tion of educational facilities to the village level, and enrich- } \\
\text { ment of educational modules related to technical aspects and } \\
\text { adaptation to formal education }\end{array}$ \\
\hline ACI2 & $\begin{array}{l}\text { Pandeglang, Lebak, Serang } \\
\text { Regency, Tangerang Regency }\end{array}$ & $\begin{array}{l}\text { Repairing and building road infrastructure, also providing } \\
\text { education and training on adaptive technology skills }\end{array}$ \\
\hline ACI3 & $\begin{array}{l}\text { All districts, except Tangerang } \\
\text { City }\end{array}$ & $\begin{array}{l}\text { Improving extension agents, recruiting new extension } \\
\text { workers, coaching, advocating and monitoring, and improv- } \\
\text { ing welfare to increase the work ethic of extension workers }\end{array}$ \\
\hline ACI4 & $\begin{array}{l}\text { Pandeglang, Lebak, Serang } \\
\text { Regency, Tangerang Regency, } \\
\text { Serang City }\end{array}$ & $\begin{array}{l}\text { Improving farmer groups' (poktan) institutions and increasing } \\
\text { the number of poktan, increasing the capacity of poktan, and } \\
\text { empowering poktan }\end{array}$ \\
\hline ACI5 & $\begin{array}{l}\text { Tangerang Regency, } \\
\text { Serang City }\end{array}$ & $\begin{array}{l}\text { Site-specific agricultural machinery assistance as needed and } \\
\text { providing spare parts, optimizing existing machinery, al- } \\
\text { so developing and engineering the Agricultural Machinery } \\
\text { Services Business Farmer Group (UPJA) }\end{array}$ \\
\hline \multirow[t]{2}{*}{ ACI6 } & $\begin{array}{l}\text { Pandeglang, Lebak, Serang } \\
\text { Regency }\end{array}$ & $\begin{array}{l}\text { Food diversification, local non-rice food development, } \\
\text { and food home area (KRPL/Kawasan Rumah Pangan Lestari) }\end{array}$ \\
\hline & $\begin{array}{l}\text { Sensitivity-Exposure Index } \\
\text { (SEI) }\end{array}$ & \\
\hline SEI1 & $\begin{array}{l}\text { Pandeglang, Serang Regency, } \\
\text { and Tangerang Regency }\end{array}$ & $\begin{array}{l}\text { Food diversification, especially from rice to non- } \\
\text { rice, particularly local food; the development of local pro- } \\
\text { duction of food technology non rice (process technology } \\
\text { and KRPL) }\end{array}$ \\
\hline SEI2 & $\begin{array}{l}\text { Tangerang City and } \\
\text { Cilegon }\end{array}$ & $\begin{array}{l}\text { Food diversification, local non-rice food development (variety } \\
\text { diversification, production and process technology), and KRPL }\end{array}$ \\
\hline SEI3 & $\begin{array}{l}\text { Pandeglang, Serang Regency, } \\
\text { and Tangerang Regency }\end{array}$ & $\begin{array}{l}\text { Increased food diversification, developed the local non- } \\
\text { rice food, and developed KRPL }\end{array}$ \\
\hline SEI4 & Pandeglang and Lebak & $\begin{array}{l}\text { Increase revenue, control the price of rice and subsi- } \\
\text { dized food of non-rice, also food diversification and KRPL }\end{array}$ \\
\hline SEI5 & None & \\
\hline SEI6 & $\begin{array}{l}\text { Tangerang, Cilegon City, } \\
\text { Serang City, and South } \\
\text { Tangerang City }\end{array}$ & $\begin{array}{l}\text { Increased production of rice and maize, and improved the } \\
\text { diversification of cropping patterns }\end{array}$ \\
\hline SEI7 & Lebak and South Tangerang & $\begin{array}{l}\text { Increase in soybean production, and repair and develop- } \\
\text { ment of irrigation infrastructure }\end{array}$ \\
\hline SEI8 & Lebak and Serang Regency & $\begin{array}{l}\text { Dissemination and implementation of water-saving } \\
\text { technology in rice cultivation, implementing irrigation net- } \\
\text { work improvement programs, repairing critical watersheds, } \\
\text { repairing and developing irrigation infrastructure, especially } \\
\text { the development of water harvessing infrastructure (reser- } \\
\text { voirs, long storage, and trench dams) and the application of } \\
\text { specific location for Integrated Crop Management (PTT) }\end{array}$ \\
\hline SEI9 & Pandeglang and Lebak & $\begin{array}{l}\text { Balance fertilization (the use of organic materials/fertilizers) } \\
\text { specific to location, using tolerant varieties, efficient fertiliza- } \\
\text { tion rice varieties, and soil management and conservation. }\end{array}$ \\
\hline SEI10 & $\begin{array}{l}\text { All districts, except } \\
\text { Pandeglang and Lebak }\end{array}$ & $\begin{array}{l}\text { Development of various sources of production/community } \\
\text { economic growth, such as household business/industrial acti- }\end{array}$ \\
\hline
\end{tabular}


vities, increasing agricultural GDP, driving the regional economy, and increasing the role of women

SEI11 None

SEI12 All districts

in Banten Province
Adapting, providing alternative water sources, farming adjusts to the climatic conditions, implementing the planting calendar, developing irrigation infrastructure and water harvesting, and using alternative water resource

SEI13 None

SEI14 All cities in Banten Province

Transmigration, which is synergized with the implementation of the agrarian reform program, review of the RTRW, and the implementation of UU No.41 / 29 P2L B

SEI15 City of Serang
Creating new agricultural lands and transmigration in synergy with the implementation of the agrarian reform program failure, the planting calendar has not been well socialized to farmers, pests (especially brown planthopper), the low rate of willingness to buy fertilizers, availability of seeds and not many farmers understand the use of superior variety, and irrigation infrastructure.

Adaptation recommendations that can be implemented in Pandeglang and Lebak for instance: (i) the need for technical handling of irrigation problems, such as repairing channels through dredging, river normalization; (ii) the use of 'caplak jarwo', traditional farming tools, for implementation 'jajar legowo' cropping system; (iii) the use of dryer to reduce the sales of wet grain; (iv) improvement on road infrastructure; (v) introducing Integrated Planting Calendar to farmers, school of field climate, and agricultural insurance or other programs that support adaptation actions that can be applied in that location; (vi) encouragement to use other superior varieties, especially those that are resistant to drought and floods; (vii) planting simultaneously to suppress the increase of pests; (viii) promoting production aspects by utilizing sub-optimal lands, idle lands, etc.; (ix) implementation of the Integrated Planting Calendar in the field to adapt with high climate variability; $(x)$ improvements on infrastructure at the farm level; and (xi) increasing farmer institutions and promoting food diversification.

\section{CONCLUSSIONS}

We found that high vulnerability of crop farming was associated with low adaptive capacity index and high sensitivity-exposure index. To decline the vulnerability level, several efforts were proposed to increase ACI and reduce SEI. Here, we used determinant factors as approach to explore the important indicators for ACI and SEI for area in Pandeglang, Lebak, Serang, and Tangerang Districts. Our findings revealed that the indicators varied among districts. For Pandeglang, $\mathrm{ACI} 3$ and SEI1 were the determinant factors, while in Lebak were ACI6 and SEI8. The determinant factors found in Tangerang were ACI2 and SEI12, whereas in Serang City and Serang were ACI4 and SEI12. Tangerang City had
SEI12 as determinant factor. On other hand, Cilegon City and Tangerang Selatan City had ACI3 and SEI12 as determinant factors.

The determinant factors found in most of the districts were SEI12, SEI4, ACI3, and ACI4. SEI12 is climate related indicator. Adaptation actions related to SEI12 include; providing alternative water sources, adapting farming to climate conditions, implementing a planting calendar, development infrastructure for irrigation and water harvest, and the use of alternative water resources. To reduce value of SEI4, several efforts were proposed, namely: food diversification, controlling rice prices and subsidy for non-rice food and building sustainable food house areas (KRPL). For ACI3 and $\mathrm{ACI} 4$, improvements were as follow: increasing the capacity and resilience of the production system through the cultivation approach including opening the new rice fields, improving human and institutional capacity, and accelerating food diversification.

\section{ACKNOWLEDGEMENTS}

The authors thank to Prof. Dr. Irsal Las, MS, and Prof. Dr. Erna Sri Adiningsih, MS for their inputs to improve the manuscript. Special thanks to Adilla, Revo, and Dariin Firda for helping in database and mapping. This paper was funded by the 2016 Agricultural land resource management policy recommendations activities financed by state budget of BALITKLIMAT (Indonesian Agro-Climate and Hydrology Resesarch Institute) with grant number 1800.107.001.412 H.

\section{REFERENCES}

Alam, M.M., Siwar, C., Talib, B.A., Wahid, A.N., 2017. Climatic changes and vulnerability of household food accessibility. International Journal of Climate Change Strategies and Management.

Ariani, M., 2019. Arah, Kendala dan Pentingnya Diversifikasi Konsumsi Pangan di Indonesia.

Bappeda Provinsi Banten, 2017. Peraturan Daerah Provinsi Banten Nomor 5 Tahun 2017 Tentang 
Perubahan Atas Peraturan Daerah Provinsi Banten Nomor 2 Tahun 2011 Tentang Rencana Tata Ruang Wilayah Provinsi Banten Tahun 2010-2030.

BMKG, 2015. Data dasarian untuk Kementan sepuluh tahun. Badan Meteorologi, Klimatologi dan Geofisika.

Bocchiola, D., Brunetti, L., Soncini, A., Polinelli, F., Gianinetto, M., 2019. Impact of climate change on agricultural productivity and food security in the Himalayas: A case study in Nepal. Agricultural Systems 171, 113-125. https://doi.org/10.1016/j.agsy.2019.01.008

Boer, R., Perdinan, Faqih, A., Amanah, S., Rakhman, A., 2015a. Kerentanan Dan Pengelolaan Risiko Iklim Pada sector Pertanian, Sumberdaya Air \& Sumber Kehidupan Masyarakat Nusa Tenggara Timur (UNDP-SPARC Project). Kementerian Lingkungan Hidup dan Kehutanan, Jakarta.

Boer, R., Rakhman, A., Faqih, A., Perdinan, Situmorang, A., 2015b. Indeks Kerentanan Dan Risiko Iklim Nusa Tenggara Timur (UNDP-SPARC Project). Kementerian Lingkungan Hidup dan Kehutanan, Jakarta.

Cains, M.G., Henshel, D., 2019. Community as an equal partner for region-based climate change vulnerability, risk, and resilience assessments. Current Opinion in Environmental Sustainability 39, 24-30.

Chinwendu, O.G., Sadiku, S., Okhimamhe, A., Eichie, J., 2017. Households vulnerability and adaptation to climate variability induced water stress on downstream Kaduna River Basin. American Journal of Climate Change 6, 247-267.

de los Ríos, C., Watson, J.E., Butt, N., 2018. Persistence of methodological, taxonomical, and geographical bias in assessments of species' vulnerability to climate change: A review. Global Ecology and Conservation 15, e00412.

Estiningtyas, W., Susanti, E., Suciantini, 2020. The efficacy of using climate data for developing food crops in wetlands: A case study from Kalimantan Island, in: Proceedings of the International Workshop on Tropical Wetlands: Innovation in Mapping and Management. Taylor \& Francis Group, London.

Estiningtyas, W., Surmaini, E., Susanti, E., 2016 a. Kerentanan Sub-sektor tanaman pangan terhadap perubahan iklim. Jurnal Sumberdaya Lahan Edisi khusus 85-96.

Estiningtyas, W., Syahbuddin, H., Harmanto, Sumaryanto, Mulyani, A., Setyorini, D., Kartiwa, B., Susanti, E., Surmaini, E., Sujono, R., Haryono, Rakhman, A., Suciantini, Apriyana, Y., Pramudia,
A., Sarvina, Y., Nengsusmoyo, C., Kurniawan, H., Nugroho, A., Samudera, R., Hutami, A., 2016b. Analisis dan Pemetaan Tingkat Kerentanan Usahatani Tanaman Pangan dan Risiko Iklim (Laporan Akhir). Balai Penelitian Agroklimat dan Hidrologi, Badan Penelitian dan Pengembangan Pertanian, Kementerian Pertanian.

Farhan, A., Ilhamsyah, Y., Akhyar, 2020. The Use of SST Anomaly to Predict Seasonal Rainfall during the Second Planting Period in the Tanoh Abee Irrigation Area, Aceh Besar. Agromet 34, 100109.

https://doi.org/10.29244/j.agromet.34.2.100109

Ford, J.D., Pearce, T., McDowell, G., Berrang-Ford, L., Sayles, J.S., Belfer, E., 2018. Vulnerability and its discontents: the past, present, and future of climate change vulnerability research. Climatic Change 151, 189-203.

Handayani, W., Rudiarto, I., Setyono, J.S., Chigbu, U.E., Sukmawati, A.M., 2017. Vulnerability assessment: A comparison of three different city sizes in the coastal area of Central Java, Indonesia. Advances in Climate Change Research 8, 286-296.

Jakariya, M., Alam, M.S., Rahman, M.A., Ahmed, S., Elahi, M.L., Khan, A.M.S., Saad, S., Tamim, H., Ishtiak, T., Sayem, S.M., 2020. Assessing climateinduced agricultural vulnerable coastal communities of Bangladesh using machine learning techniques. Science of the Total Environment 742, 140255.

Kantamaneni, K., Rice, L., Yenneti, K., Campos, L.C., 2020. Assessing the Vulnerability of Agriculture Systems to Climate Change in Coastal Areas: A Novel Index. Sustainability 12, 4771.

Koutroulis, A., Papadimitriou, L., Grillakis, M., Tsanis, I., Warren, R., Betts, R., 2019. Global water availability under high-end climate change: $A$ vulnerability-based assessment. Global and Planetary Change 175, 52-63.

Kukal, M.S., Irmak, S., 2018. Climate-driven crop yield and yield variability and climate change impacts on the US Great Plains agricultural production. Scientific Reports 8, 1-18.

Lee, Y.-J., 2017. A synthesized biophysical and social vulnerability assessment for Taiwan. E\&ES 94, 012161.

Mallari, A.E.C., 2016. Climate change vulnerability assessment in the agriculture sector: Typhoon Santi experience. Procedia-Social and Behavioral Sciences 216, 440-451. 
Menike, L., Arachchi, K., 2016. Adaptation to climate change by smallholder farmers in rural communities: Evidence from Sri Lanka. Procedia food science 6, 288-292.

Morel, A.C., Hirons, M., Demissie, S., Gonfa, T., Mehrabi, Z., Long, P.R., Rifai, S., Gole, T.W., Mason, J., McDermott, C.L., 2019. The structures underpinning vulnerability: examining landscape-society interactions in a smallholder coffee agroforestry system. Environmental Research Letters 14, 075006.

Mulyaqin, T., 2020. The Impact of El Niño and La Nina on Fluctuation of Rice Production in Banten Province. Agromet 34, 34-41. https://doi.org/10.29244/j.agromet.34.1.34-41

Naylor, A., Ford, J., Pearce, T., Van Alstine, J., 2020. Conceptualizing Climate Vulnerability in Complex Adaptive Systems. One Earth 2, 444454.

Neset, T.-S., Wiréhn, L., Opach, T., Glaas, E., Linnér, B.-O., 2019. Evaluation of indicators for agricultural vulnerability to climate change: The case of Swedish agriculture. Ecological Indicators 105, 571-580.

Noy, I., Yonson, R., 2018. Economic vulnerability and resilience to natural hazards: A survey of concepts and measurements. Sustainability 10 , 2850.

Oldeman, L.R., 1975. An Agro-climate map of Java [Indonesia]. Contribution from the Central Research Institute for Agriculture, Bogor.

Pandey, R., Jha, S.K., Alatalo, J.M., Archie, K.M., Gupta, A.K., 2017. Sustainable livelihood frameworkbased indicators for assessing climate change vulnerability and adaptation for Himalayan communities. Ecological Indicators 79, 338346.

Papathoma-Köhle, M., Cristofari, G., Wenk, M., Fuchs, S., 2019. The importance of indicator weights for vulnerability indices and implications for decision making in disaster management. International journal of disaster risk reduction 36, 101103.

Perdinan, Boer, R., Rakhman, A., Situmorang, A., Zulaikha, M., Nurbaeti, B., 2015. Pilihan Adaptasi Perubahan Iklim Nusa Tenggara
Timur (UNDP-SPARC Project). Kementerian Lingkungan Hidup dan Kehutanan, Jakarta.

Purwantini, T.B., Saptana, S., Suharyono, S., 2016. Program kawasan rumah pangan lestari (KRPL) di Kabupaten Pacitan: analisis dampak dan antisipasi ke depan. Analisis Kebijakan Pertanian 10, 239-256.

Reinmuth, E., Parker, P., Aurbacher, J., Högy, P., Dabbert, S., 2017. Modeling perceptions of climatic risk in crop production. PloS one 12, e0181954.

Rondhi, M., Fatikhul Khasan, A., Mori, Y., Kondo, T., 2019. Assessing the role of the perceived impact of climate change on national adaptation policy: the case of rice farming in Indonesia. Land 8, 81.

Rufat, S., Tate, E., Burton, C.G., Maroof, A.S., 2015. Social vulnerability to floods: Review of case studies and implications for measurement. International Journal of Disaster Risk Reduction $14,470-486$.

Saptutyningsih, E., Diswandi, D., Jaung, W., 2020. Does social capital matter in climate change adaptation? A lesson from agricultural sector in Yogyakarta, Indonesia. Land use policy 95, 104189.

Sujakhu, N.M., Ranjitkar, S., Niraula, R.R., Salim, M.A., Nizami, A., Schmidt-Vogt, D., Xu, J., 2018. Determinants of livelihood vulnerability in farming communities in two sites in the Asian Highlands. Water International 43, 165-182.

Thomas, K., Hardy, R.D., Lazrus, H., Mendez, M., Orlove, B., Rivera-Collazo, I., Roberts, J.T., Rockman, M., Warner, B.P., Winthrop, R., 2019. Explaining differential vulnerability to climate change: $A$ social science review. Wiley Interdisciplinary Reviews: Climate Change 10, e565.

Tyler, S., Nugraha, E., Nguyen, H.K., Van Nguyen, N., Sari, A.D., Thinpanga, P., Tran, T.T., Verma, S.S., 2016. Indicators of urban climate resilience: $A$ contextual approach. Environmental science $\&$ policy $66,420-426$.

Wichern, J., Descheemaeker, K., Giller, K.E., Ebanyat, P., Taulya, G., van Wijk, M.T., 2019. Vulnerability and adaptation options to climate change for rural livelihoods-A country-wide analysis for Uganda. Agricultural Systems 176, 102663. 